\title{
Aspects of nitrogen use efficiency of cauliflower $I$. A simulation modelling based analysis of nitrogen availability under field conditions
}

\author{
H. KAGE*, C. ALT AND H. STÜTZEL \\ Institute for Vegetable and Fruit Crops, University of Hannover, Herrenhäuser Str. 2, \\ D-30419 Hannover, Germany
}

(Revised MS received 8 May 2003)

\begin{abstract}
SUMMARY
Data from several field experiments (eight crops grown under a widely varying nitrogen supply on a loess loam soil) were used for a simulation modelling based analysis of nitrogen availability of cauliflower. The model was built out of components describing root growth, nitrate transport to the roots and the vertical nitrate transport within the soil.

Root observations obtained over 2 years indicated an increased fraction of dry matter allocated to the fine roots under $\mathrm{N}$ deficiency. An adapted version of a root growth model for cauliflower described the rooting data with an $R^{2}=0 \cdot 75$. Based upon an acceptable description of the soil water budget, vertical nitrate movement during the growth period of cauliflower was accurately described. The magnitude of this movement, however, was limited to soil depths of about $60 \mathrm{~cm}$ even after periods of high rainfall, because of a high soil water holding capacity. An analysis of the factors determining nitrate availability indicated that apparent mass flow was only of high importance for conditions of extremely high $\mathrm{N}$ supply where high amounts of nitrate nitrogen remain in the soil up to the end of the growing season. Otherwise, the dominating fraction of nitrate has to be transported to the roots by diffusion. Single root model based calculations of maximum nitrate transport to roots overestimated $\mathrm{N}$ availability as indicated by estimates of critical soil nitrate $\mathrm{N}$ that were too low. The introduction of a restricted uptake activity period of the roots was used to bridge the gap between theoretical calculations and empirical results. Scenario calculations were carried out to obtain functional relationships between $\mathrm{N}$ supply and residual soil nitrate levels for different soil conditions and management practices.
\end{abstract}

\section{INTRODUCTION}

Crops from intensive vegetable cropping systems like cauliflower often have high nitrogen uptake rates because of high nitrogen contents of their organs and high growth rates (Van den Boogaard \& ThorupKristensen 1997; Schenk 1998). However, these crops also have mostly comparable low total root lengths (Jackson 1995), especially when cultivated as transplants (Thorup-Kristensen 1993; Kage et al. 2000). This agronomic practice shortens their growth period on the field and thereby the time available for the root

* To whom all correspondence should be addressed. Present address: Institute of Agronomy and Plant Breeding, University of Kiel, Hermann-Rodewald-Str. 6, D-24118 Kiel, Germany. Email: kage@pflanzenbau.uni-kiel.de system to exploit the soil volume. High specific nutrient influx rates therefore have to be maintained throughout the crop's growing period in order to ensure maximum growth (Burns 1980). Under similar conditions this is only possible with higher soil nitrogen contents than for crops with higher total root length. Higher residual soil nitrogen contents, however, may lead to leaching losses and therefore to a decrease of the nitrogen use efficiency of the cropping system and to environmental pollution (De Neve \& Hofman 1998).

Because of the high mobility of the nitrate ion in the soil solution most crops are able to exhaust the soil down to very low nitrate concentrations and thereby sustain nitrate influx rates sufficient for satisfying the nitrogen demand of the crop (De Willigen \& 
Table 1. Type of experiment ( $L T=$ long term, $A=$ annual), year, planting and harvest dates, average incident photosynthetic active radiation, I, and average temperature during the growth period of the cauliflower experiments used in this study

\begin{tabular}{lcccccc}
\hline \hline Type & Year & Planting date & Harvest date & $\begin{array}{c}\text { Average I } \\
\left(\mathrm{MJ} / \mathrm{m}^{2} \text { per day }\right)\end{array}$ & $\begin{array}{c}\text { Average temperature } \\
\left({ }^{\circ} \mathrm{C}\right)\end{array}$ & $\begin{array}{c}\text { No. of N } \\
\text { treatments }\end{array}$ \\
\hline LT & 1994 & 97 & 185 & $8 \cdot 13$ & $13 \cdot 12$ & 2 \\
LT & 1994 & 207 & 293 & $5 \cdot 45$ & $14 \cdot 52$ & 2 \\
LT & 1995 & 94 & 187 & $7 \cdot 59$ & $12 \cdot 13$ & 2 \\
LT & 1995 & 200 & 291 & $6 \cdot 10$ & $16 \cdot 49$ & 2 \\
LT & 1996 & 100 & 189 & $7 \cdot 41$ & $12 \cdot 59$ & 2 \\
LT & 1996 & 200 & 284 & $6 \cdot 18$ & $14 \cdot 34$ & 4 \\
A & 1996 & 170 & 240 & $7 \cdot 78$ & $16 \cdot 08$ & 4 \\
A & 1997 & 190 & 258 & $7 \cdot 23$ & $18 \cdot 56$ & 4 \\
\hline \hline
\end{tabular}

Van Noordwijk $1987 a$ ). Critical conditions for nitrate availability can therefore be found in the sub soil, where rooting density is low (Wiesler \& Horst 1994) or for crops with very sparse root systems (Kage 1997).

Kage et al. (2002) showed that for a loess loam soil under ample water supply amounts of soil mineral nitrogen of about $40-50 \mathrm{~kg} \mathrm{~N} / \mathrm{ha}$ in the upper $60 \mathrm{~cm}$ of the soil profile must be maintained to sustain leaf protein contents of cauliflower at an optimal level. Such an empirical analysis is hampered by the fact that changing soil conditions, an altered water regime or a different distribution of the mineral nitrogen in the soil profile may change considerably this empirical value for critical soil mineral nitrogen contents.

The aim of the present paper therefore is to analyse the availability of soil nitrogen for cauliflower using a mechanistic model approach. For this purpose a previously published model for root growth of cauliflower (Kage et al. 2000) is combined with a mechanistic model for soil nitrate availability (Baldwin et al. 1973; Kage 1997) based on the single root approach (Gardner 1960). Data from two annual and one long-term field experiments summing up to eight crops grown over a wide range of nitrogen supply are used for the analysis in the present paper. Furthermore scenario calculations were carried out to quantify potential leaching losses during the growing period on a hypothetical sandy soil and to derive functional dependencies between nitrogen supply rate and residual soil nitrate levels.

\section{MATERIAL AND METHODS}

\section{Field experiments}

The field experiments used in the present study belong to two different groups. The first group is from two annual nitrogen fertilization trials from 1996 and 1997 (Alt 1999). Additionally, data from a long-term crop rotation experiment are used for further model evaluation. These experiments have previously been described in Kage \& Stützel (1999b), but for the present study reduced $\mathrm{N}$ supply treatments are also included in the analysis.

All field experiments were conducted on the same experimental farm located $15 \mathrm{~km}$ south of Hannover, Germany, on a typical loess derived hapludalf soil. Crops were established in the field using transplants grown in peat cubes of $4 \mathrm{~cm}$ edge length and the average visible leaf number at planting ranged from 2.9 to 4.03 leaves per plant. Crop husbandry in all experiments was designed to ensure that crop growth was not limited by the availability of water. Pesticides were applied when needed to ensure healthy growth.

Nitrogen fertilization was given as ammonium nitrate at the time of transplanting only for the annual experiments. Soil nitrate content of $10-15 \mathrm{~kg} \mathrm{~N} / \mathrm{ha}$ in 1996 and 1997 in the $0-60 \mathrm{~cm}$ soil layer were subtracted from $150(\mathrm{~N} 1), 300(\mathrm{~N} 2)$ and $450 \mathrm{~kg} / \mathrm{ha}(\mathrm{N} 3)$ target values. Furthermore a N0 treatment was included, which received no nitrate nitrogen. For the long-term experiment a nitrogen fertilization schedule according to the KNS system (Lorenz et al. 1989) was applied, defining two target values of $130 \mathrm{~kg} \mathrm{~N} / \mathrm{ha}$ from $0-30 \mathrm{~cm}$ soil depth at transplanting and of $270 \mathrm{~kg} \mathrm{~N} / \mathrm{ha}$ from $0-60 \mathrm{~cm}$ soil depth about 4 weeks after transplanting. The two $\mathrm{N}$ treatments received either $100 \%$ of this recommended $\mathrm{N}$ supply level or a reduced N supply of $70 \%$ of this level in 1994 and 1995 and of $50 \%$ of this level in 1996.

Temperature and radiation data were taken from measurements of an automated weather station (Campbell Sci. Ltd., UK) located on the experimental station. Measured values of global radiation were converted to photosynthetic active radiation, I, using a factor of 0.5 (Szeicz 1974). Average values of I and air temperature at $2 \mathrm{~m}$ height for the experimental years are shown in Table 1.

Soil cores were extracted at the last harvest of the annual experiments in 1996 in all nitrogen treatments and in 1997 in the N0 and N2 treatment only using a special root auger of $8 \mathrm{~cm}$ diameter (Eijkelkamp 
Agriresearch Equipment, Giesbeek, NL) down to a depth of $90 \mathrm{~cm}$ in $15 \mathrm{~cm}$ increments. Samples were taken at two positions within a field plot, one beneath a cauliflower plant and one in a mid-row position. Soil cores were stored at $4{ }^{\circ} \mathrm{C}$ until roots were washed out over a $1.25 \mathrm{~mm}$ sieve and root length was determined after removing organic debris from the sample using the method of Newman (1966).

Soil mineral $\mathrm{N}$ was determined down to a depth of $120 \mathrm{~cm}$ in four intervals of $30 \mathrm{~cm}$ thickness. From every plot six auger samples were collected. Soil nitrate $\mathrm{N}$ was measured photometrically at a wave length of $210 \mathrm{~nm}$ after extraction with $0.025 \mathrm{~N} \mathrm{CaCl}_{2}$ (Navone 1964). One tensiometer per plot was installed shortly after transplanting at depths of 20, 40, 70 and $90 \mathrm{~cm}$, respectively in the annual experiment in 1997 and in the crops of the long-term experiment.

There was generally an exceptionally high variation in the data of soil water tension and soil nitrate for the late planted crops of the long-term experiment (Table 1). The reasons are the need for irrigation of these crops, which was carried out using a micro sprinkler technique inducing a substantial local variation of water supply, and the incorporation of crop residues from the previous cauliflower crop. From these crops only net mineralization data are presented here.

\section{Calculation of net mineralization}

Net mineralization was calculated for every treatment and for periods between soil and plant analyses separately from the data of soil nitrate nitrogen from $0-120 \mathrm{~cm}$ and measurements of shoot dry matter and nitrogen content. An additional amount of 10 and $5 \%$ of measured shoot nitrogen was assumed to be located in the root part of the fertilized and unfertilized plants, respectively, and net mineralization was corrected for that.

\section{Model}

\section{Root growth}

The root growth model module used in this study is described in detail by Kage et al. (2000). Roughly, it calculates the total root length based on the fraction of dry matter allocated to the root system and using a constant average specific root length for conversion of root dry matter into root length. The increase of rooting depth is derived using a simple temperature sum based approach and the vertical distribution of root length is described using a negative exponential function. However, some modifications of the original model module are included to account for (a) the effects of root ageing on water and nitrogen uptake and (b) the effects of an altered dry matter partitioning under nitrogen stress.

The nitrate uptake properties of roots clearly change during ageing, therefore a decrease of the maximum nitrate capacity can be observed (Reidenbach \& Horst 1997). The assumption that all roots are fully active in nitrate and water uptake, which is often made within crop growth models (Benjamin et al. 1996), is therefore invalid. However, studies on the temporal change of root activity under field conditions are still lacking. We therefore tried to bridge this knowledge gap in a very simple way. Roots are assumed to be fully active during a certain time span from their initial occurrence (active duration, $A D$ ) and are assumed to be fully non-active afterwards. Using this simplification it is possible to calculate an effective root length $R L_{\text {eff }}$ and rooting density $R L D_{\text {eff }}$ for all soil layers, $i$, from the total root length and their distribution in different age classes, $j$ :

$$
R L_{\text {eff }}=\sum_{j=1}^{j \times \mathrm{d} t \leqslant A D} \text { RLmat }_{i, j}
$$

The two dimensional matrix $R L_{m a t}$ is updated in daily time steps, thereby all elements of the matrix are shifted one step forward in the time dimension, $j$ :

$$
R L_{i, j}=R L_{i, j-1}
$$

The first grid cell in every layer becomes the actual increase in root length, if positive:

$$
R L_{i, 1}=\max \left(0, \frac{\mathrm{d} R L}{\mathrm{~d} t}\right)
$$

From the effective root length, the effective root length density is calculated:

$$
R L D_{\text {eff }}=R L_{\text {eff }} / \Delta z
$$

It is well known that the fraction of assimilates allocated to the roots increases under restricted nitrogen (Ericsson 1995) or water supply (Huck et al. 1986) and this behaviour motivated the postulation of the functional equilibrium law (Brouwer 1962). In the present work, this effect is also considered in a simplistic manner, assuming that the fraction of assimilates allocated to the fine roots, $f_{f r}(-)$, is increased to a maximum value $f_{\text {frmax }}$ during periods of nitrogen deficiency, i.e. when the $\mathrm{N}$ demand, $N_{d e m}$ is higher than the $\mathrm{N}$ supply, $N_{\text {sup }}$, and decreased to the value of unstressed plants $f_{f r 0}$ if the nitrogen supply is sufficient:

$$
\begin{aligned}
& \frac{\mathrm{d} f_{f r}}{\mathrm{~d} t}= \\
& \left\{\begin{array}{ll}
f_{f r} \times r_{f f r}\left(1-\frac{f_{f r}}{f_{f r m a x}}\right) & N_{d e m}>N_{\text {sup }}, \\
-\left(f_{f r m a x}-f_{f r}+f_{f r 0}\right) \times r_{f f r}\left(1-\frac{f_{f r}}{f_{f r 0}}\right) & N_{d e m} \leqslant N_{s u p}
\end{array},\right.
\end{aligned}
$$

Thereby the parameter $r_{f f r}$ (per day) determines the rapidity of the adaptation process. Here an estimated 
Table 2. Parameters of the Van Genuchten-Mualem equations found by fitting to data on soil water tension v. soil water content

\begin{tabular}{|c|c|c|c|c|c|c|c|}
\hline Soil & Depth $(\mathrm{cm})$ & $\theta_{r}\left(\mathrm{~cm}^{3} / \mathrm{cm}^{3}\right)$ & $\theta_{s}\left(\mathrm{~cm}^{3} / \mathrm{cm}^{3}\right)$ & $\alpha$ per $\mathrm{cm}$ & $n$ & $l^{*}$ & $K_{s}^{*}(\mathrm{~cm} /$ day $)$ \\
\hline \multirow[t]{3}{*}{ Loess loam } & $0-30$ & $0 \cdot 0$ & 0.4295 & $0 \cdot 01479$ & $1 \cdot 276$ & 0.5 & 7 \\
\hline & $30-80$ & 0.0347 & 0.4367 & 0.00903 & 1.448 & 0.5 & 7 \\
\hline & $80-200$ & $0 \cdot 0$ & $0 \cdot 4485$ & 0.00675 & $1 \cdot 238$ & $0 \cdot 5$ & 7 \\
\hline \multirow[t]{2}{*}{ Sandy (Scenario) } & $0-30$ & $0 \cdot 0$ & 0.4429 & 0.0332 & 1.336 & 0.5 & $40 \cdot 19$ \\
\hline & $30-200$ & $0 \cdot 0$ & $0 \cdot 3800$ & $0 \cdot 01997$ & 1.627 & $0 \cdot 5$ & 50 \\
\hline
\end{tabular}

* Estimated value.

value of $0 \cdot 2$ was used, assuming that the shift of the allocation process has a time scale in the order of days rather than hours or weeks.

\section{Water transport}

Vertical water transport in the soil profile is calculated using the water content-based formulation of the Richard's equation. The relationships between soil water diffusivity and the volumetric soil water content were described using the functions suggested by van Genuchten (1980) in the revised form of Wösten \& Genuchten (1988). The necessary parameters for this relationship were estimated with the program RETC (van Genuchten et al. 1991) using data from Künkele (1996) and H. Bohne (1999, personal communication) for the loess loam soil of the experimental site. Additionally, parameters for a sandy soil were derived for a scenario calculation using data taken from Wösten et al. (1986) (Table 2).

The sink term $S(\psi)_{, i}$ in the layer $i$ of the finite difference scheme is calculated from a hypothetical maximum sink term $S_{\max }(\psi)_{, i}$ that is defined by the following equation:

$$
S_{\max , i}(\psi)=T_{p} \frac{R L D_{i}{ }^{c f}}{\sum_{1}^{n_{r}} R L D_{i}{ }^{c f}}
$$

where $T_{p}$ is the potential transpiration rate, $R L D_{i}$ is the rooting density in the layer $i, n_{r}$ is the number of the rooted compartments computed from the maximum rooting depth $z_{r}$ and the thickness of the layers, $\Delta z$. The parameter $c f$ is an empirical factor that accounts for root competition. This factor is set to a value of 0.5 according to the results of Ehlers et al. (1991) and Kage \& Ehlers (1996).

The maximum sink term $S_{\max }(\psi)_{, i}$ is converted to the actual sink term $S(\psi)_{, i}$ by multiplication with an empirical reduction factor $\alpha(\psi)$ as described by Feddes et al. (1978). This factor was assumed to decline from a value of one at matrix potentials $\geqslant-1000 \mathrm{hPa}$ down to zero at $-20000 \mathrm{hPa}$.

\section{Evapo-transpiration}

Potential evaporation is calculated using the PenmanMonteith equation (Monteith 1973). Net radiation,
$R_{n}$, was computed from the global radiation, $G R$, using an empirical regression equation derived from measurements of global and net radiation over grass at the experimental field 'Ruthe':

$$
R_{n}=0.6494 \times G R-18.417
$$

Potential evaporation is the sum of potential transpiration, $T_{p}$, potential evaporation, $E_{p}$, and of interception evaporation, $I$ :

$$
E T_{p}=T_{p}+E_{p}+I
$$

Interception evaporation $\mathrm{kg} / \mathrm{m}^{2}$ per day is assumed to take place from a storage pool, $I P\left(\mathrm{~kg} / \mathrm{m}^{2}\right)$, situated on the surface of the canopy. The capacity of this storage pool, CIP $\left(\mathrm{kg} / \mathrm{m}^{2}\right)$, is calculated from a specific interception capacity, SIC $\left(\mathrm{kg} / \mathrm{m}^{2}\right.$ per $\left.\mathrm{m}^{2}\right)$, and the leaf area index $L A I \mathrm{~m}^{2} / \mathrm{m}^{2}$.

$$
C I P=S I C \times L A I
$$

Interception is the minimum of the sum of the maximum possible change of the interception pool and the precipitation rate, $\mathrm{Pr}, \mathrm{kg} / \mathrm{m}^{2}$ per day and the potential evapo-transpiration:

$$
I=\min \left(I P / \mathrm{d} t+\min (\operatorname{Pr}, C I P-I P), E T_{p}\right)
$$

The change of the storage pool is calculated from the minimum of the precipitation rate and the actual unused capacity of the precipitation pool, $C I P-I P$ :

$$
\frac{\mathrm{d} I P}{\mathrm{~d} t}=\min (\operatorname{Pr}, C I P-I P)-I
$$

The potential evaporation rate is determined by the fraction of radiation energy which is reaching the soil surface. This value is computed from the leaf area index of the crop and the extinction coefficient for global radiation.

Actual evaporation was determined from an empirical function using potential evaporation and the water potential in $10 \mathrm{~cm}$ depth as input parameters (Beese et al. 1978). The potential transpiration is calculated as the remaining part of the potential evapotranspiration after subtracting potential evaporation and interception and also taking into account an empirical crop resistance. 


\section{Soil nitrogen balance}

In well-aerated soils the concentration of ammonium is usually very low compared with that of nitrate, therefore only nitrate nitrogen is considered by the model.

\section{Vertical nitrate transport}

Vertical nitrate transport in the soil profile is calculated by a numerical solution of the convectiondispersion equation (Addiscott \& Wagenet 1985). The initial condition for this equation was the measured nitrate concentration from 0 to $120 \mathrm{~cm}$, which was determined in a spatial resolution of $30 \mathrm{~cm}$. Since no $N_{\min }$ measurements were available for depths below $120 \mathrm{~cm}$, all layers from 100 to $200 \mathrm{~cm}$ were initialized with the measured $N_{\min }$ content of the layer 90-120 cm depth.

\section{Nitrate uptake by plant roots}

It is assumed that the nitrate uptake by the plants root system $U R_{a c t}\left(\mathrm{~g} \mathrm{~N} / \mathrm{m}^{2}\right.$ per day) is determined either by the nitrogen demand of the plants $N_{\text {dem }}$ or the maximum nitrate transport rate to the root system $U R_{\max }$ :

$$
\begin{array}{ll}
U R_{\max }<N_{\text {dem }}: & U R_{a c t}=U R_{\max } \\
U R_{\max }>N_{\text {dem }}: & U R_{a c t}=N_{\text {dem }}
\end{array}
$$

Nitrogen demand of plants is derived from the sum of demand of the plant organs:

$$
N_{\text {dem }}=\sum N_{\text {dem, } i}
$$

The latter is computed from their growth rate and their nitrogen content under optimal $\mathrm{N}$ supply as described in Kage et al. (2000).

\section{Nitrogen transport to roots}

The maximum nitrogen transport rate to roots, $I_{\text {mmax }}$ ( $\mathrm{g} \mathrm{N} / \mathrm{cm}$ per day), is calculated using the single root model approach (Gardner 1960) for which Baldwin et al. (1973) developed an analytical solution assuming steady state conditions. A modified version of this equation was used in the present study. For details of the derivation of this equation see Kage (1997).

In this equation a minimum concentration $C_{l \min }$ is used, defined as the lowest concentration where nitrate uptake matches transport to roots (De Willigen \& Van Noordwijk 1987a). Since most plant species (Peuke \& Kaiser 1996) are very efficient in nitrate uptake, this value will be usually very low $\left(<10^{-7} \mathrm{~mol} / \mathrm{cm}^{3}\right)$, which is equivalent to less than $1 \mathrm{~kg} \mathrm{~N}$ in a $30 \mathrm{~cm}$ soil layer, a volumetric water content of $30 \%$. Therefore, the exact value of this parameter is not very important and can be set to zero, as it was done in the present study, in order to calculate the maximum uptake rate.

For each rooted soil layer $i$ the maximum nitrate uptake rate $A R_{\max , i}(\mathrm{~g} / \mathrm{cm}$ per day) is computed from the maximum nitrate influx rate $I_{\text {nmax }, i}(\mathrm{~g} / \mathrm{cm}$ per day) and the root length in that particular layer $R L_{i}$ $\left(\mathrm{cm} / \mathrm{cm}^{2}\right)$ :

$$
A R_{\text {max }, i}=I_{\text {nmax }, i} \times R L_{i}
$$

The maximum $\mathrm{N}$ supply rate $\left(N_{\text {sup }}\right)\left(\mathrm{g} \mathrm{N} / \mathrm{m}^{2}\right.$ per day) is then simply the sum of all maximum uptake rates corrected for the changed units of area:

$$
N_{\text {sup }}=\sum A R_{\text {max }, i} \times 10^{4}
$$

The sink term of the convection dispersion equation then is computed either from the nitrogen demand and the proportion of the maximum nitrate uptake rate to the sum of the maximum uptake rate in all rooted soil layers, or if the sum of the maximum uptake rates is smaller than the nitrogen demand the sink term is simply the maximum uptake rate itself:

$$
S_{i}=\left\{\begin{array}{cl}
A R_{\text {max },_{i}} & N_{\text {dem }} \geqslant N_{\text {sup }} \\
N_{\text {dem }} \times 10^{-4} \times \frac{A R_{\text {max },_{i}}}{\sum_{i=1}^{i \Delta z=z_{r}} A R_{\text {max },_{i}}} & N_{\text {dem }}<N_{\text {sup }}
\end{array}\right.
$$

The total $\mathrm{N}$ uptake rate, $U R_{a c t}$, from the soil then is the sum of the sink terms in all soil layers.

\section{Parameter estimation and statistics}

The whole model is implemented within the HUME modelling environment (Kage \& Stützel 1999a). This modelling environment supports parameter estimation based on the Marquardt algorithm (Marquardt 1963). The parameter estimate for $f_{f R \max }$ (Eqn 5) was obtained by minimizing the squared sum of differences between measured and simulated $R L D$ values from the annual experiment in 1996.

For evaluation the goodness of fit of the model output linear regression analysis and the statistical measures modelling efficiency $(E F)$ and root mean square error (RMSE) used:

$$
\begin{gathered}
E F=1-\frac{\sum\left(y_{i}-\hat{y}_{i}\right)^{2}}{\sum\left(y_{i}-\bar{y}_{i}\right)^{2}} \\
R M S E=\sqrt{\frac{\sum\left(y_{i}-\hat{y}_{i}\right)^{2}}{n}}
\end{gathered}
$$

where $y_{i}$ and $\hat{y}_{i}$ are the measured and predicted values, respectively and $n$ is the number of observations.

\section{RESULTS}

There is a tendency of decreasing net mineralization rates with increasing nitrogen fertilization (Table 3 ) in the annual experiments. For the rotation experiment no clear influence of nitrogen fertilization on calculated net mineralization could be found. For the 
Table 3. Calculated average net mineralization rate ( $\mathrm{kg} \mathrm{N} / \mathrm{ha}$ per day) during crop growing period in two experimental years under four different nitrogen supply rates $(\mathrm{NO}-\mathrm{N} 3)$

\begin{tabular}{lrr}
\hline \hline N supply rate & 1996 & 1997 \\
\hline N0 & $0 \cdot 728$ & $1 \cdot 173$ \\
N1 & $0 \cdot 014$ & $0 \cdot 835$ \\
N2 & $-0 \cdot 168$ & $0 \cdot 709$ \\
N3 & $1 \cdot 276$ & $0 \cdot 386$ \\
\hline \hline
\end{tabular}

Table 4. Calculated average net mineralization rate ( $\mathrm{kg} N /$ ha per day) in three experimental years under two different nitrogen supply rates $\left(\mathrm{N}_{\text {norm }}, \mathrm{N}_{\mathrm{red}}\right)$

\begin{tabular}{|c|c|c|c|c|c|c|}
\hline \multirow[b]{2}{*}{ Planting } & \multicolumn{2}{|c|}{1994} & \multicolumn{2}{|c|}{1995} & \multicolumn{2}{|c|}{1996} \\
\hline & Early & Late & Early & Late & Early & Late \\
\hline$N_{\text {norm }}$ & $0 \cdot 517$ & $5 \cdot 389$ & $0 \cdot 241$ & $0 \cdot 847$ & $0 \cdot 509$ & 1.75 \\
\hline$N_{\text {red }}$ & $0 \cdot 242$ & $3 \cdot 414$ & 0.650 & 1.059 & $0 \cdot 510$ & 0.92 \\
\hline
\end{tabular}
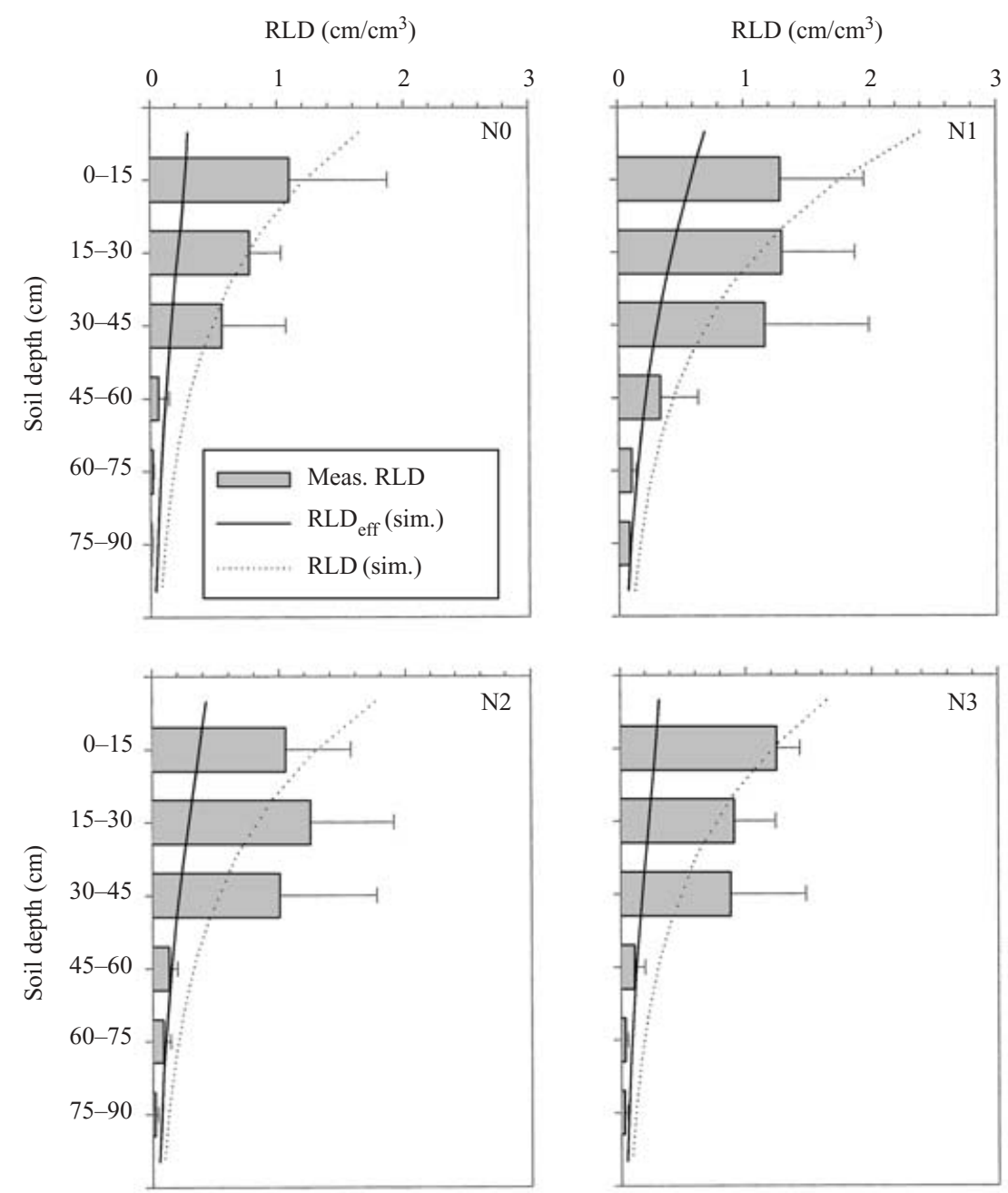

Fig. 1. Measured and simulated root length density $(R L D) v$. soil depth at end of the growing period for cauliflower crops grown under 4 different $\mathrm{N}$ supply treatments $(\mathrm{N} 0 \ldots \mathrm{N} 3)$ in 1996. Simulated $R L D$ is shown for total $(R L D)$ and effective root length density $\left(R L D_{\text {eff }}\right)$. Error bars indicate standard error of the mean. The linear regression equation between measured and simulated $R L D$ is $y=0 \cdot 17( \pm 0 \cdot 0884)+0 \cdot 95( \pm 0 \cdot 12) x, R^{2}=0 \cdot 75, n=24$. 

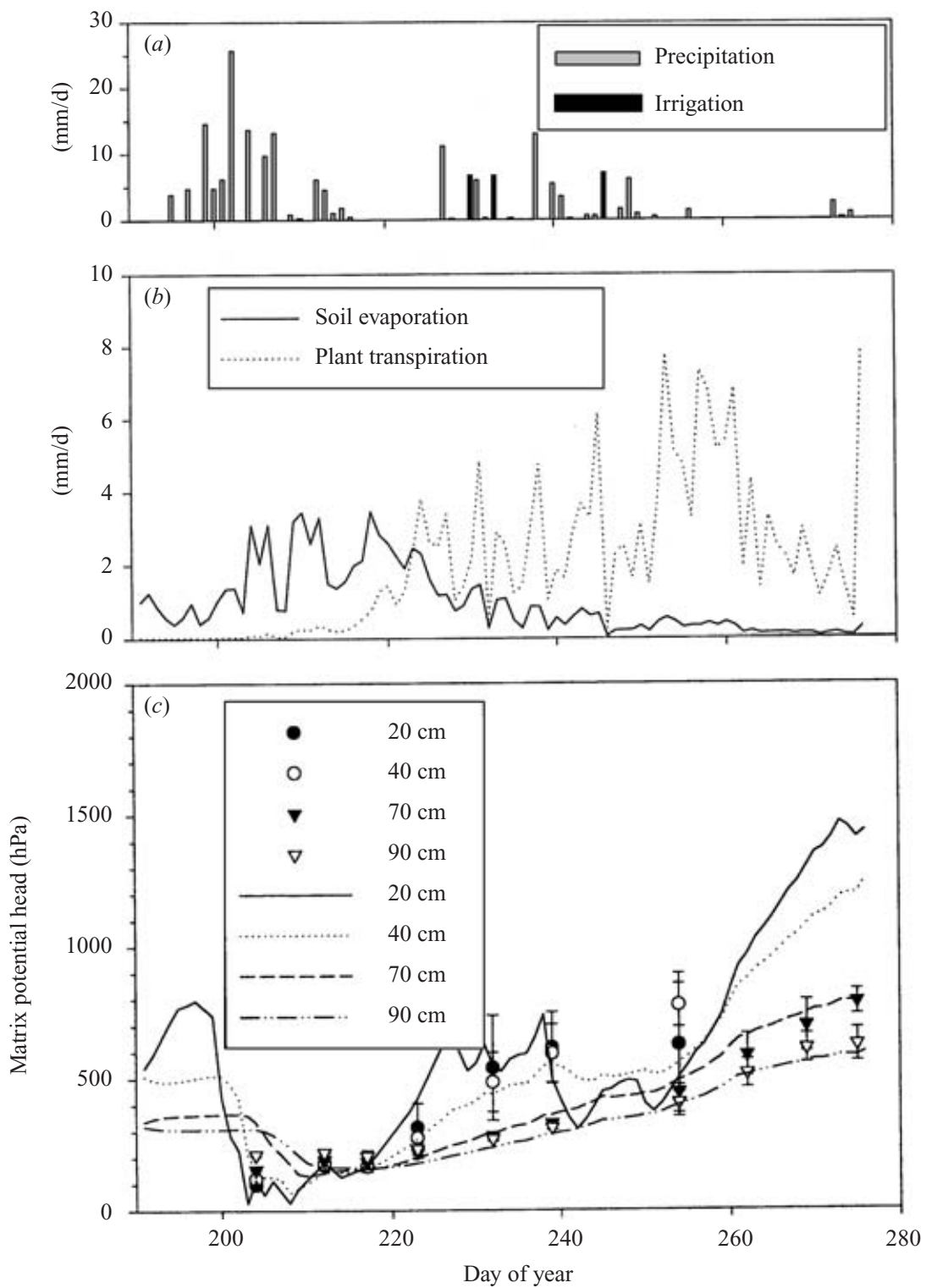

Fig. 2. Precipitation and irrigation during experimental period, calculated soil evaporation and plant transpiration as well as measured and simulated soil matrix potential head in different soil depths from transplanting to last harvest of the optimal fertilized (N2) cauliflower treatment in 1997.

second cauliflower crops, however, clearly higher net mineralization rates were calculated (Table 4).

The $R L D$ values of the different $\mathrm{N}$ treatments in 1996 (Fig. 2) and 1997 (data not shown) did not differ substantially, despite the indication of a more pronounced root distribution of the N0 treatment in 1996 compared with the $\mathrm{N} 2$ treatment. This indicates that the fraction of dry matter allocated to the fine root fraction was elevated under nitrogen deficiency. The parameter $f_{f R \max }$ (Eqn 5) was estimated by adjustment to the 1996 data at a value of $0.201( \pm 0.004)$. This was the only parameter specifically adjusted using data from the present experiments. Using this parameter value the $R L D$ data of the $\mathrm{N}$ deficient treatments N0 and N1 in 1996 could be described in a way that the simulated distribution of the root length density was within the standard deviation of the measurements of this parameter (Fig. 2). Also, the 
Table 5. Parameters of a linear regression analysis between measured and simulated soil water tensions $(h P a)$ as well as residual mean square error (RMSE) and modelling efficiency (EF). Data are from the 1997 annual experiment and from the early planted crops of the long-term experiment

\begin{tabular}{lrrcccc}
\hline $\begin{array}{l}\text { Soil } \\
\text { depth } \\
\text { (cm) }\end{array}$ & Slope & Intercept & $R^{2}$ & $n$ & $R M S E$ & $E F$ \\
\hline 20 & $1 \cdot 1724$ & $-58 \cdot 1560$ & 0.6214 & 38 & $106 \cdot 8452$ & $0 \cdot 5962$ \\
40 & $2 \cdot 5354$ & $-278 \cdot 7340$ & $0 \cdot 5753$ & 38 & $99 \cdot 8982$ & $0 \cdot 3637$ \\
70 & $1 \cdot 9471$ & $-155 \cdot 0777$ & 0.3509 & 38 & $66 \cdot 0248$ & $0 \cdot 1525$ \\
\hline
\end{tabular}

prediction for the 1997 data was acceptable, with some minor discrepancies between simulated and measured values for the somewhat deeper distributed root system of the N0 treatment (data not shown).

The high amount of rainfall at the beginning of the experiment in 1997 (Fig. 2a) lowered the soil water potential down to values close to field capacity up to a soil depth of $90 \mathrm{~cm}$ (Fig. 2 c). Due to soil evaporation and plant transpiration (Fig. $2 b$ ) the simulated absolute values of soil water potential rises to about 1500 $\mathrm{hPa}$ in the topsoil but remained at about $700 \mathrm{hPa}$ in the subsoil. For the other evaluated crops a sufficient description of soil water tensions was also achieved (Table 5).

The soil nitrate content in 1996 changed substantially only in the upper $30 \mathrm{~cm}$ of the profile, where the fertilized nitrogen was exhausted rapidly after onset of plant nitrogen uptake (Fig. 3). Due to the low N contents of the deeper soil layers and the absence of leaching during the 1996 vegetation period, changes of soil nitrate in deeper soil layers $(>30 \mathrm{~cm})$ were small. The excess of rainfall at around the 210th day of the year (DOY 210) in 1997 (Fig. 2a) induced downward water movement, which transported some nitrate nitrogen from the upper $30 \mathrm{~cm}$ of the soil profile to the layer 30-60 cm (Fig. 4). However, due to the high water capacity of the loess loam this leaching process did not affect soil nitrate contents below a depth of $60 \mathrm{~cm}$ (Fig. 4). With the exception of the N3 treatment the soil mineral $\mathrm{N}$ content was exhausted down to values less than $50 \mathrm{~kg} \mathrm{~N}$ during the growing period. Simulated and measured values for the different soil layers also agreed sufficiently well for the other evaluated crops (Table 6).

The stimulated $\mathrm{N}$ uptake rates of the $\mathrm{N} 2$ and N3 treatments were, during the time of highest $\mathrm{N}$ demand, above $8 \mathrm{~kg} \mathrm{~N} /$ ha per day (1996: Fig. 5; 1997: data not shown). However, due to the high $\mathrm{N}$ amounts (Fig. 3) in the comparably dense rooted topsoil (Fig. 1), calculated maximum nitrate transport rates to the root system were always (N3) or until a few days before
Table 6. Parameters of a linear regression analysis between measured and simulated soil nitrate nitrogen in different soil layers as well as residual mean square error (RMSE) and modelling efficiency (EF). Data are from the 1996 and 1997 annual experiments and from the early plantings of the long-term experiment

\begin{tabular}{lccccrr}
$\begin{array}{l}\text { Soil } \\
\text { depth } \\
\text { (cm) }\end{array}$ & Slope & Intercept & $R^{2}$ & $n$ & $R M S E$ & $E F$ \\
\hline $0-30$ & $0 \cdot 9819$ & $5 \cdot 8324$ & $0 \cdot 9336$ & 47 & $28 \cdot 0339$ & $0 \cdot 9319$ \\
$30-60$ & $0 \cdot 5309$ & $5 \cdot 8549$ & $0 \cdot 4380$ & 47 & $12 \cdot 2148$ & $0 \cdot 0251$ \\
$60-90$ & $1 \cdot 1340$ & $0 \cdot 0772$ & $0 \cdot 7274$ & 47 & $3 \cdot 5219$ & $0 \cdot 6855$ \\
$90-120$ & $1 \cdot 0726$ & $0 \cdot 2127$ & $0 \cdot 7670$ & 47 & $3 \cdot 8381$ & $0 \cdot 7499$ \\
$0-120$ & $0 \cdot 9575$ & $8 \cdot 4942$ & $0 \cdot 9303$ & 47 & $32 \cdot 0057$ & $0 \cdot 9278$ \\
\hline \hline
\end{tabular}

final harvest (N2) higher than calculated $\mathrm{N}$ uptake. This indicates unrestricted (N3 treatment) or almost unrestricted (N2) N availability for the crops. The suboptimal (N2) and unfertilized (N0) treatments, however, were calculated to be limited in $\mathrm{N}$ uptake by $\mathrm{N}$ availability in the second half of the growing period (N1) or throughout the growing period (N0) (Fig. 5). The N1 treatment was calculated to be $\mathrm{N}$ limited from DOY 210 on wards at a soil nitrate content $0-60 \mathrm{~cm}$ of $67 \mathrm{~kg} \mathrm{~N} / \mathrm{ha}$. Hereby an active uptake period of 10 days was assumed (Eqn 1). Assuming an unrestricted uptake period of the roots, however, indicated an $\mathrm{N}$ limitation on DOY 218 at a soil mineral $\mathrm{N}$ content of $18 \mathrm{~kg} \mathrm{~N} /$ ha (Fig. 5).

The computed apparent mass flow rates were close to the calculated plant uptake rate for the first half of the growing period in the case of the super optimal fertilized N3 treatment. For all other treatments actual $\mathrm{N}$ uptake rates were generally much lower than calculated apparent mass flow rates (Fig. 5). Average nitrogen influx rates show an initial phase of increase shortly after planting, but steadily decrease thereafter. Peak values are higher than $5 / 10^{12} \mathrm{~mol} \mathrm{~N} / \mathrm{cm}$ per second if calculated using total root length and about $15 / 10^{12} \mathrm{~mol} \mathrm{~N} / \mathrm{cm}$ per second if calculated using an 'effective' root length (Fig. 6).

A scenario calculation was carried out for the N2 treatments of both years using the soil hydraulic parameters of a sandy soil instead of the parameters for the loess soil (Table 2). All other input values were left unchanged. Due to the lower water capacity of this soil type the calculated downward movement of nitrate during the vegetation periods of both years was more pronounced than was measured and simulated at the loess loam location (Figs 3 and $4 v$. Fig. 7). But the rainfall-induced downward movement of water and nitrate was limited to a soil depth of about $60 \mathrm{~cm}$. This limited translocation of nitrate, however, increased the amount of unused soil mineral nitrogen left in the soil at 30-60 cm compared with the loess 

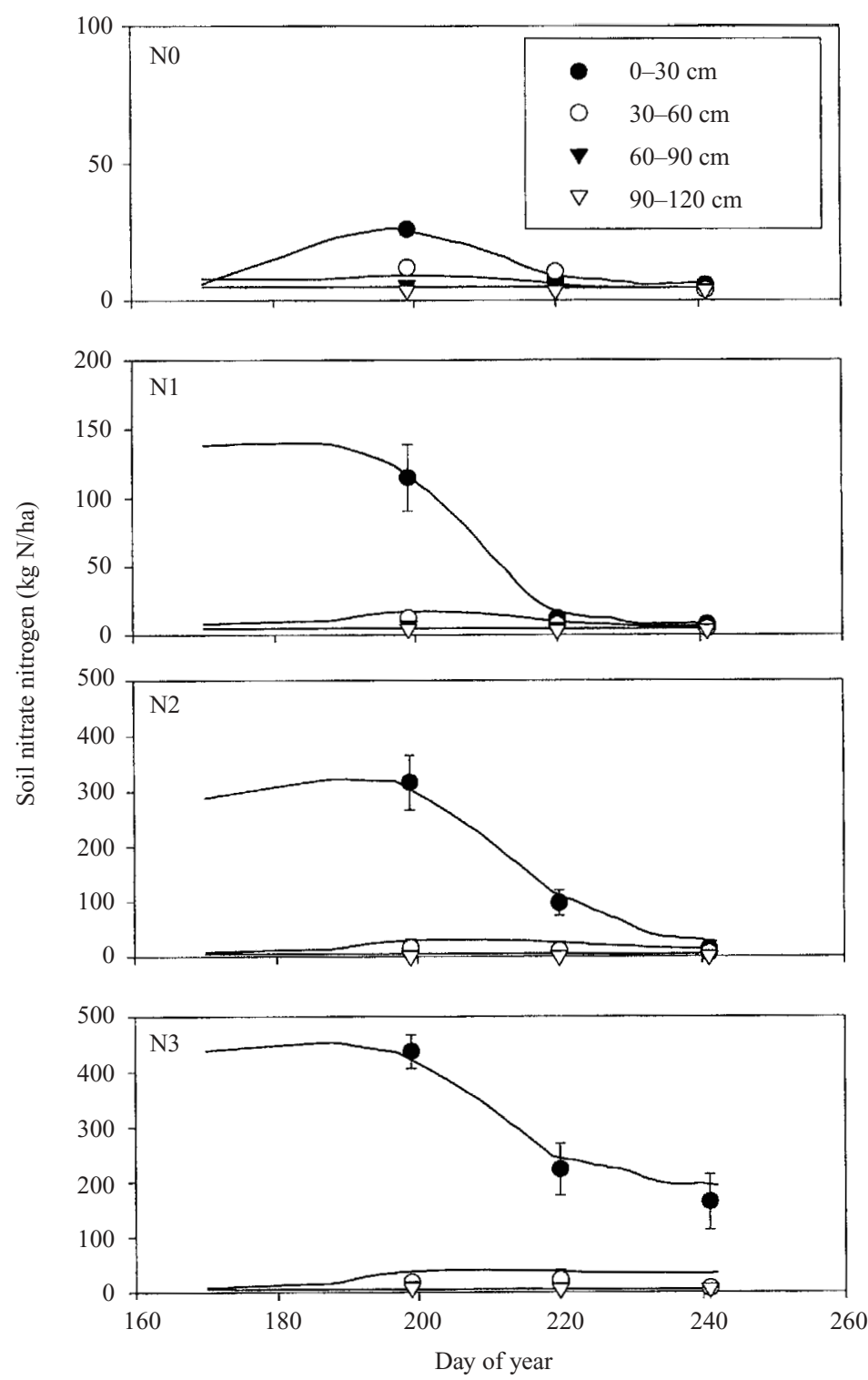

Fig. 3. Measured and simulated soil mineral nitrogen content of the 1996 cauliflower experiment of the $4 \mathrm{~N}$ treatments. Error bars indicate the standard error of the mean.

loam soil conditions, especially under 1997 weather conditions (Fig. 7).

A further scenario calculation was carried out to obtain response curves of residual soil nitrate at harvest from $0-120 \mathrm{~cm}$ soil depth to $\mathrm{N}$ fertilization. Again, two different sets of hydraulic parameters were used, the parameter set for the loess soil of the experimental field and another of a sandy soil (Table 2). On the sandy soils possible effects of a split nitrogen application were also evaluated assuming a fixed nitrogen application at planting of $100 \mathrm{~kg} \mathrm{~N} / \mathrm{ha}$ and varied secondary application 4 weeks after planting. For N mineralization rate the same values as shown in Table 3 for the N2 treatment in 1997 were used.

Residual soil nitrate values remain at low values of about $20 \mathrm{~kg} \mathrm{~N} / \mathrm{ha}$ up to a $\mathrm{N}$ fertilization of about $200 \mathrm{~kg} \mathrm{~N} / \mathrm{ha}$ for the loess loam soil conditions and about $50 \mathrm{~kg} \mathrm{~N} / \mathrm{ha}$ up to $150 \mathrm{~kg} \mathrm{~N} / \mathrm{ha}$ fertilization for the standy soil (Fig. 8). Split nitrogen application on the sandy soil is calculated to delay the increase of residual soil nitrate towards a higher level of $\mathrm{N}$ supply. Starting at an $\mathrm{N}$ fertilization of about $250 \mathrm{~kg} \mathrm{~N} / \mathrm{ha}$, 

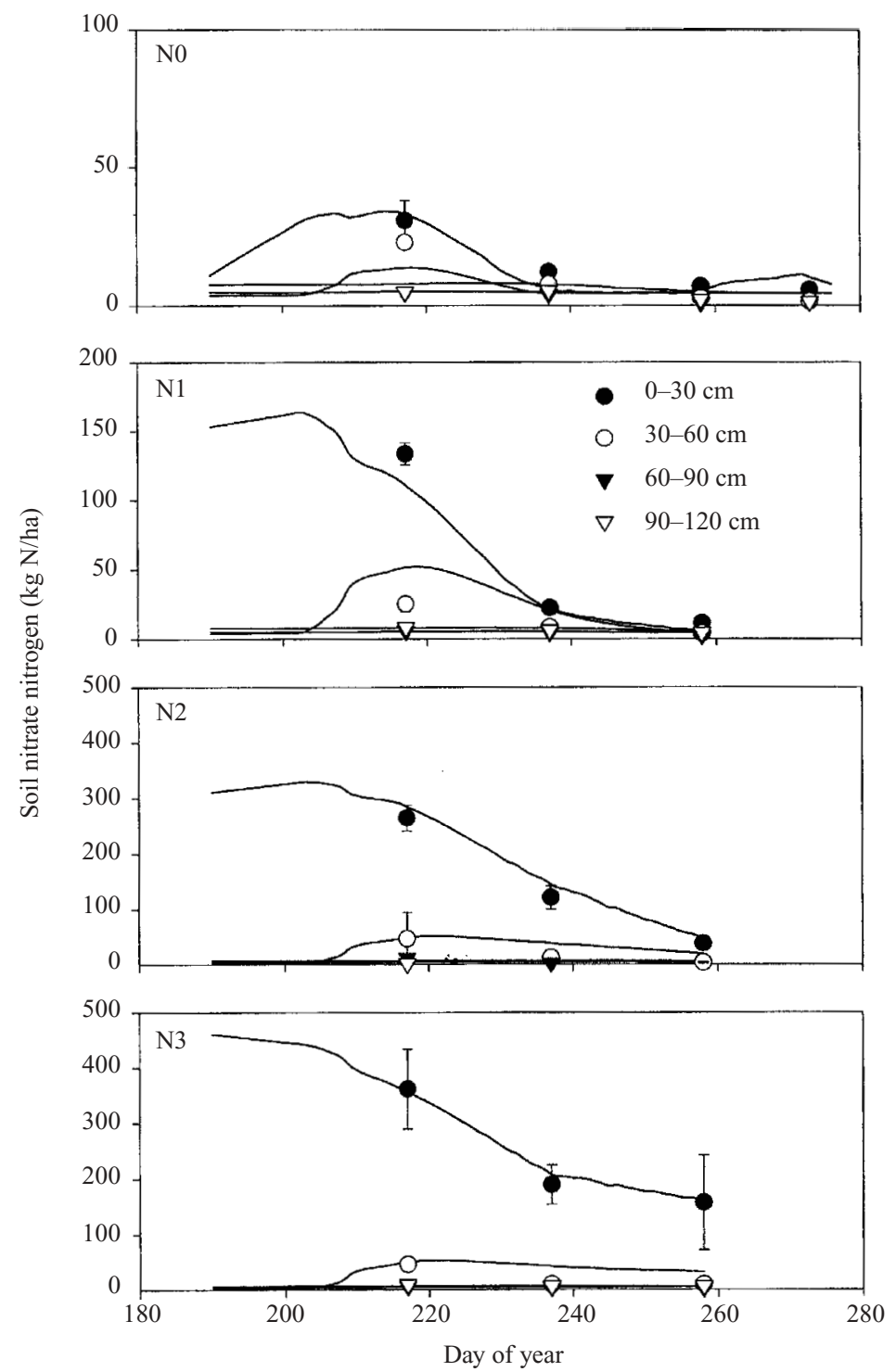

Fig. 4. Measured and simulated soil material nitrogen content of the 1997 cauliflower experiment of the $4 \mathrm{~N}$ treatments. Error bars indicate the standard error of the mean.

the sink capacity of the cauliflower is saturated and residual soil nitrate levels are increasing linearly for all conditions considered in the calculation.

\section{DISCUSSION}

The aim of the present work was to quantify the nitrogen availability for cauliflower crops grown under different nitrogen supplies using a mechanistic simulation model. Furthermore scenario calculations were carried out to estimate effects of altered soil conditions.
The adapted root growth module from Kage et al. (2000) sufficiently described the temporo-spatial pattern of root length density (Fig. 1). The discrepancy of measured and simulated $R L D$ in $75-90 \mathrm{~cm}$ depth of the N0 treatment in the annual experiment of 1996, however, indicates that even small amounts of nitrogen in the sub soil (Fig. 3) may induce local deviations of the root profile from the negative exponential shape predicted by the model if nitrogen is deficient. Such 'irregular' root growth patterns may be much more severe if roots of $\mathrm{N}$ deficient plants tap into sub soil regions with high $\mathrm{N}$ nitrate concentrations (Drew 


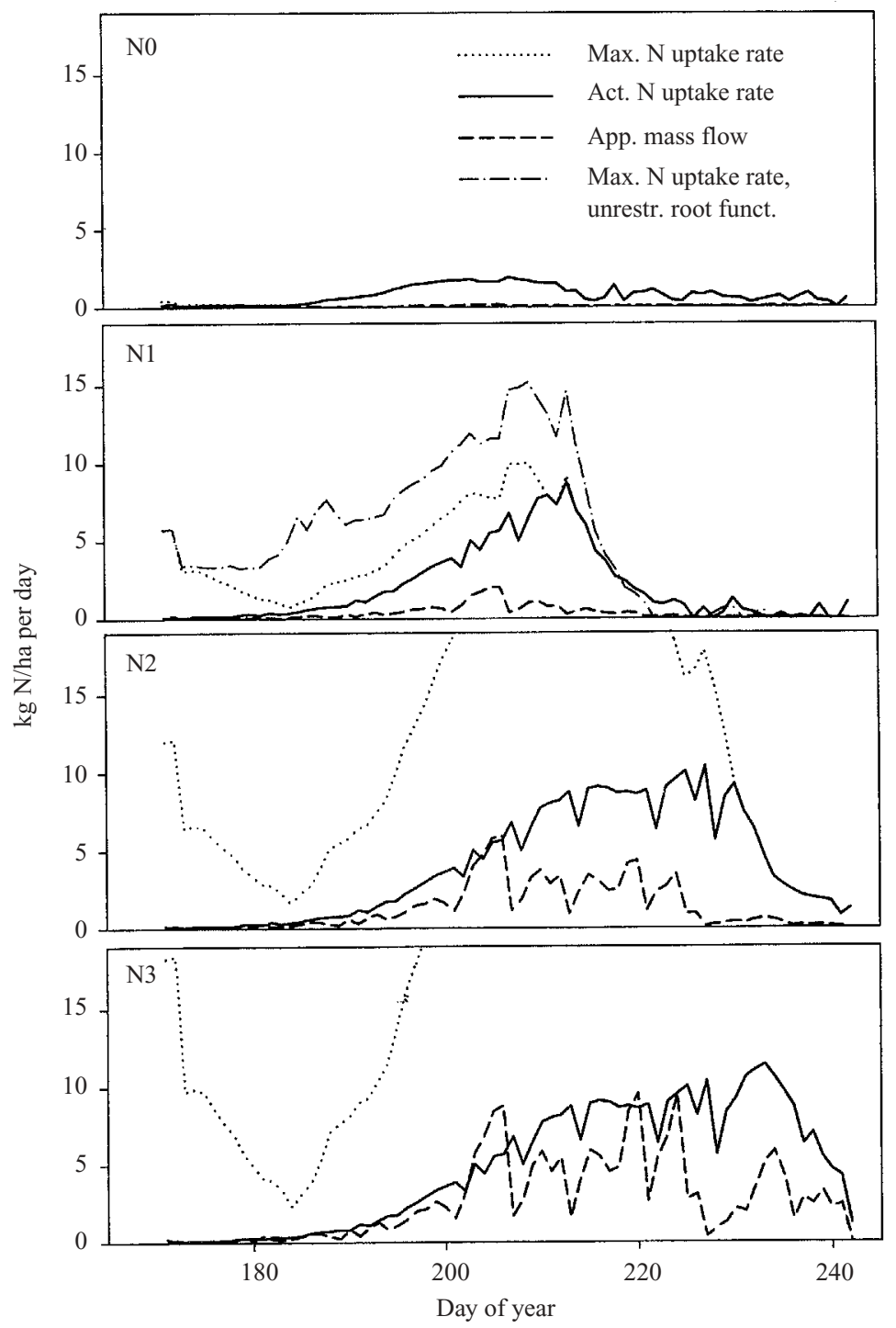

Fig. 5. Simulated maximum nitrate transport rates to the root system, apparent mass flow and actual $\mathrm{N}$ uptake rates of cauliflower from the 1996 experiment for 4 different $\mathrm{N}$ treatments.

\& Saker 1975; Burns 1991). The approach taken in the present paper to account for a changing assimilate partitioning between roots and shoots under nitrogen deficiency (Eqn 5) accurately described the data obtained (Fig. 2) even under a quite extreme variation of $\mathrm{N}$ supply. But it may fail to predict responses of rooting intensity under different soil conditions, because the beneficial effect of an increased root growth on $\mathrm{N}$ uptake depends clearly on particular soil conditions such as water content and the vertical distribution of nitrate in the soil profile. Teleonomic approaches, explaining shoot-root partitioning with growth maximizing principles (Thornley 1972; Johnson \& Thornley 1987; Kleemola et al. 1996) may be superior for this purpose. However, their elaboration and parameterization calls for more detailed data than those which were available in the present study.

The good agreement between simulated and measured soil nitrate in different soil layers (Figs 3 and 4) is mainly due to the good description of the time course of crop nitrogen uptake by the model modules presented in the second part of this work because net mineralization was input and downward movement of nitrate was, even in 1997, of limited 


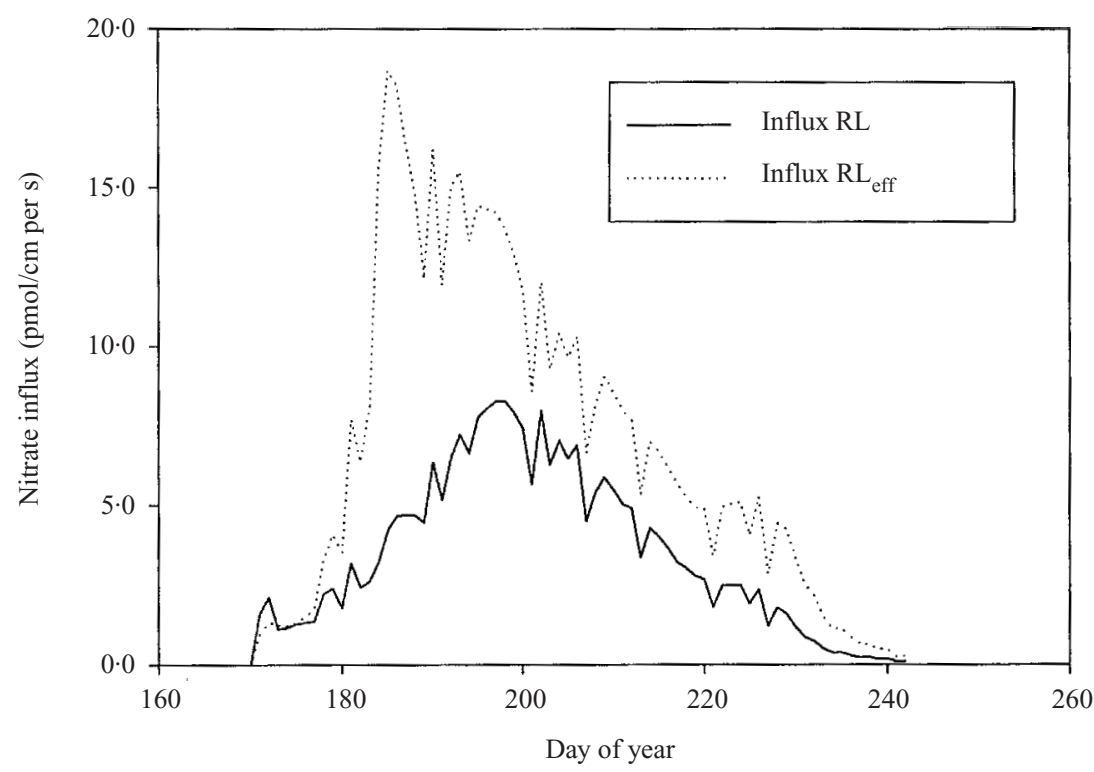

Fig. 6. Calculated $\mathrm{N}$ influx (N uptake per units root length) using either simulated total (RL) or effective root length (RL $\left.\mathrm{L}_{\text {eff }}\right)$ for the $\mathrm{N} 2$ treatment of the 1996 annual experiment.

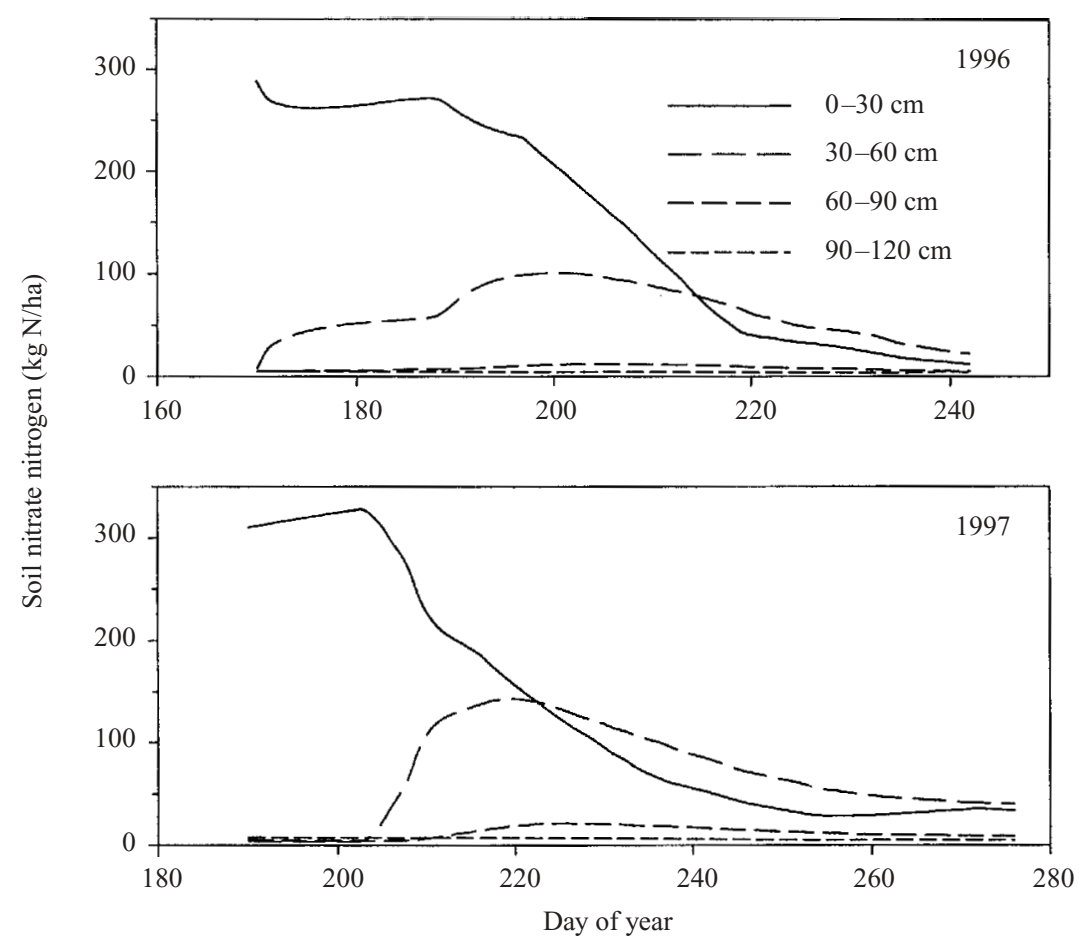

Fig. 7. Simulated soil nitrate content in different layers for a scenario calculation using soil hydraulic parameters of a sandy soil for the N2 treatments of the 1996 and 1997 experiments. 


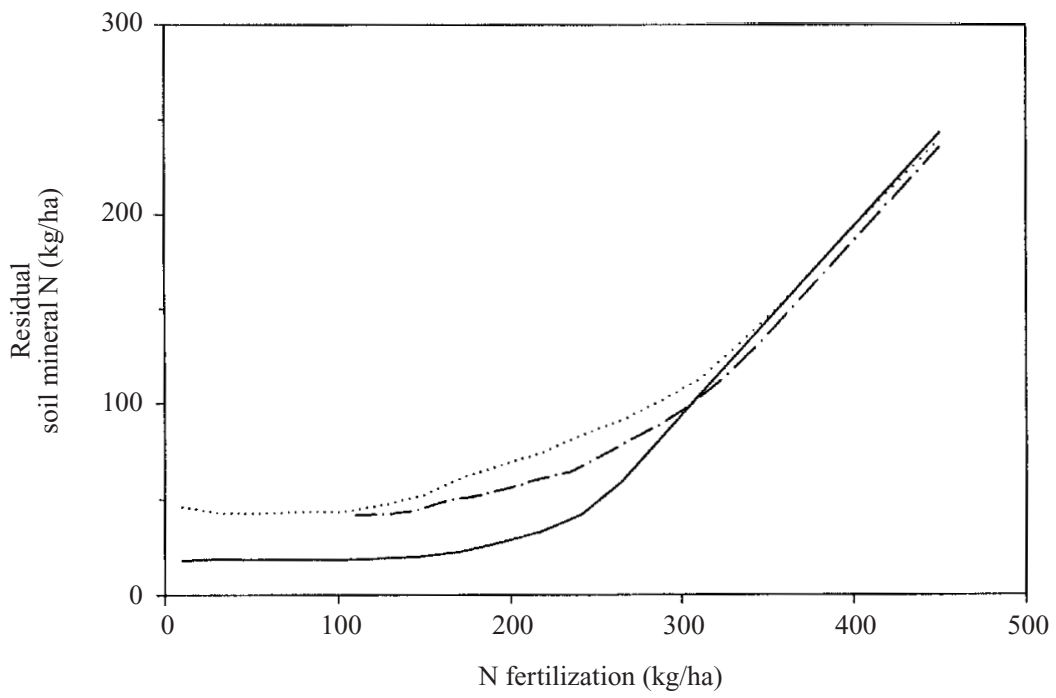

Fig. 8. Residual soil nitrate from $0-120 \mathrm{~cm}$ under varying nitrogen fertilization rates for a loess loam soil, a sandy soil and a sandy soil with split $\mathrm{N}$ application. All other input variables as in the 1997 annual experiment (-, loess loam soil; $\cdots \cdots \cdot$, sandy soil; --.----., sandy soil with split nitrogen application).

importance for soil nitrogen dynamics (Fig. 4). As shown in Tables 3 and 4 there is a substantial variation of net mineralization depending presumably on seasonal variations of soil temperature, the preceding crop (Greenwood et al. 1996) and the amount of $\mathrm{N}$ fertilization (Blankenau \& Kuhlmann 2000).

The calculation presented in Fig. 5 clearly demonstrates that mass flow is only able to contribute substantially to the nitrate transport to roots if the soil nitrate concentration is very high, as already stated by Strebel \& Duynisveld (1989) and Kage (1996). The estimated nitrate influx rates for the whole root system are about one order of magnitude higher than values reported for winter wheat (Barraclough 1986; Robinson et al. 1994) and winter rape (Barraclough 1989). This is due to an additive effect of higher nitrogen uptake rates of cauliflower per unit of ground area (Fig. 6) and a lower total root length (Kage et al. 2000) compared with both agricultural crops mentioned above. Influx rates are almost doubled for the calculated effective root length. These high influx values are the prerequisite for the reproduction of the high critical soil nitrate values found in the field (Alt et al. 2000) by the single root model.

The scenario calculation for the sandy soil (Figs 7 and 8) indicates that even for this soil type leaching losses of nitrogen out of the root zone during the growing period of cauliflower are limited. However, it has to be stated that at the beginning of the growing period nitrate nitrogen was situated predominantly in the upper $30 \mathrm{~cm}$ of the soil in both years. But even the limited calculated downward movement of nitrate lowers the availability because of the lower rooting density in the sub soil (Fig. 1), resulting in somewhat increased residual soil nitrate level in the $30-60 \mathrm{~cm}$ layer (Fig. 7). Due to the different water content-soil water potential characteristic of the sandy soil the calculated water contents are lower in the sandy soil compared with the loess loam. This also reduces nitrate availability because nitrate diffusion is closely dependent on the soil water content. Critical soil nitrate levels and consequently residual soil nitrate levels are therefore higher for sandy soils than for loamy soils (Fig. 8). For both soil types residual soil nitrogen values are increasing only after the $\mathrm{N}$ uptake capacity of the cauliflower crop is reached. This behaviour has also been found for other crops like winter wheat (Chaney 1990).

The postulation of a limited active duration of root functioning used in the present study is a very crude approach to bridge the gap between observed critical soil nitrate concentrations (Alt et al. 2000) and the predictions obtained using an unrestricted functional time of roots (Fig. 5). The estimation of this active duration by adjustment with respect to measured and simulated critical soil nitrate values lumps the effects of all unrealistic simplifications of the model into one causal factor. Consequently, a presumably much too low value of a 10-day period of $\mathrm{N}$ uptake was found to give an acceptable prediction of critical soil nitrogen content (Figs 3 and 5). Other candidates for explaining elevated predictions of the model for maximum nitrate uptake rates of the root system are: (a) horizontally uneven root distribution (Baldwin et al. 1972; De Willigen \& Van Noordwijk 1987 b; Kage 1992; Droogers et al. 1997), (b) limited soil-root contact 
(Herkelrath et al. 1977; De Willigen \& Van Noordwijk 1987a), (c) locally decreased soil water contents around water-absorbing roots (Herkelrath et al. 1977; Hainsworth \& Aylmore 1986; Kage \& Ehlers 1996), (d) horizontally uneven distribution of soil nitrate (Van Noordwijk \& Wadman 1992; Hodge et al. 1999). The incorporation of these effects into the model may reduce the contradiction between the functional time of roots in the model and physiologically realistic values, but would also increase the number of unknown and hardly measurable model parameters. The approach of an effective root length presented here may therefore be regarded as acceptable, since it preserves the mechanistic character of the single root model approach and may therefore give realistic predictions even when extrapolated to other experimental conditions. However, it also clearly focuses the knowledge gap between empirically determined critical soil nitrogen contents and the prediction of mathematical models of root functioning.

\section{CONCLUSIONS}

Root growth of cauliflower under nitrogen deficiency could be described as increasing the fraction of dry matter allocated to the fine root fraction. Rooting depth and vertical root distribution were obviously not severely affected. A mechanistic model of nitrate availability calculated lower critical soil nitrogen contents than were empirically derived. Critical soil nitrate values may be higher for sandy than for soils with a higher water-holding capacity.

\section{REFERENCES}

Addiscott, T. M. \& Wagenet, R. J. (1985). Concepts of solute leaching in soils: a review of modelling approaches. Journal of Soil Science 36, 411-424.

Alt, C. (1999). Modelling nitrogen demand in cauliflower (Brassica oleracea $L$. botrytis) using productivity-nitrogen relationships. Ph.D. Thesis, University of Hannover, Hannover.

Alt, C., Kage, H. \& Stützel, H. (2000). Der Einfluß von Stickstoff auf Morphologie und Physiologie des Blattapparates. Gibt es optimale N-Gehalte? Pflanzenbauwissenschaften 2, 103-112.

Baldwin, J. P., Nye, P. H. \& Tinker, P. B. (1973). Uptake of solutes by multiple root systems from soil. III. A model for calculating the solute uptake by a randomly dispersed root system developing in a finite volume of soil. Plant and Soil 38, 621-635.

Baldwin, J. P., Tinker, P. B. \& Nye, P. H. (1972). Uptake of solutes by multiple root systems from soil. II. The theoretical effects of rooting density and pattern on uptake of nutrients from soil. Plant and Soil 36, 693-708.

Barraclough, P. B. (1986). The growth and activity of winter wheat roots in the field: nutrient inflows of highyielding crops. Journal of Agricultural Science, Cambridge 106, 53-59.

Barraclough, P. B. (1989). Root growth, macro-nutrient uptake dynamics and soil fertility requirements of a highyielding winter oilseed rape crop. Plant and Soil 119, 59-70.

Barraclough, P. B. \& Tinker, P. B. (1981). The determination of ionic diffusion coefficients in field soils. I. Diffusion coefficients in sieved soils in relation to water content and bulk density. Journal of Soil Science 32, 225-236.

Beese, F. \& Wierenga, P. J. (1980). The variability of the apparent diffusion coefficient in undisturbed soil columns. Zeitschrift für Pflanzenernährung und Bodenkunde 146, 302-315.

Beese, F., Van Der Ploeg, R. R. \& Richter, W. (1978). Der Wasserhaushalt einer Löß-Parabraunerde unter Winterweizen und Brache. Computermodelle und ihre experimentelle Verifizierung. Zeitschrift für Acker und Pflanzenbau 146, 1-19.
Benjamin, J. G., Ahuja, L. R. \& Allmaras, R. R. (1996). Modelling corn rooting patterns and their effects on water uptake and nitrate leaching. Plant and Soil 179, 223-232.

Blankenau, K. \& Kuhlmann, H. (2000). Effect of N supply on apparent recovery of fertilizer $\mathrm{N}$ as crop $\mathrm{N}$ and Nmin in soil during and after cultivation of winter cereals. Journal of Plant Nutrition and Soil Science 163, 91-100.

Brouwer, R. (1962). Distribution of dry matter in the plant. Netherlands Journal of Agricultural Science 10, 361-376.

Burns, I. G. (1980). Influence of the spatial distribution of nitrate on the uptake of $\mathrm{N}$ by plants: a review and a model for rooting depth. Journal of Soil Science 31, 155-173.

BuRNS, I. G. (1991). Short- and long-term effects of a change in the spatial distribution of nitrate in the root zone and $\mathrm{N}$ uptake, growth and root development of young lettuce plants. Plant, Cell and Environment 14, 21-33.

Chaney, K. (1990). Effect of nitrogen fertilizer rate on soil nitrate nitrogen content after harvesting winter wheat. Journal of Agricultural Science, Cambridge 114, 171-177.

De Neve, S. \& Hofman, G. (1998). N mineralization and nitrate leaching from vegetable crop residues under field conditions: a model evaluation. Soil Biology and Biochemistry 30, 2067-2075.

De Willigen, P. \& Van NoordwiJk, M. (1987a). Roots, plant production and nutrient use efficiency. Ph.D. Thesis, Agricultural University Wageningen, The Netherlands.

De Willigen, P. \& Van NoordwiJk, M. (1987b). Uptake potential of non-regularly distributed roots. Journal of Plant Nutrition 10, 1273-1281.

Drew, M. C. \& SAKer, L. R. (1975). Nutrient supply and the growth of the seminal root system in barley. II. Localized, compensatory increases in lateral root growth and rates of nitrate uptake when nitrate supply is restricted to only part of the root system. Journal of Experimental Botany 26, 79-90.

Droogers, P., Van Der Meer, F. B. W. \& Bouma, J. (1997). Water accessibility to plant roots in different soil 
structures occurring in the same soil type. Plant and Soil 188, 83-91.

Ehlers, W., Hamblin, A. P., Tennant, D. \& Van Der Ploeg, R. R. (1991). Root system parameters determining water uptake of field crops. Irrigation Science 12, 115-124

Ericsson, T. (1995). Growth and shoot: root ratio of seedlings in relation to nutrient availability. Plant and Soil 169, 205-214.

Feddes, R. A., Kowalik, P. J. \& Zaradny, H. (1978). Simulation of Field Water Use and Crop Yield. Wageningen: PUDOC.

GARDNER, W. R. (1960). Dynamic aspects of water availability to plants. Journal of Soil Science 89, 63-73.

Greenwood, D. J., Rahn, C., Draycott, A., Vaidyanathan, L. V. \& Paterson, C. (1996). Modelling and measurement of the effects of fertilizer- $\mathrm{N}$ and crop residue incorporation on $\mathrm{N}$-dynamics in vegetable cropping. Soil Use and Management 12, 13-24.

Hainsworth, J. M. \& Aylmore, L. A. G. (1986). Water extraction by single plant roots. Soil Science Society of America Journal 50, 841-848.

Herkelrath, W. N., Miller, E. E. \& Gardner, W. R. (1977). Water uptake by plants. II. The root contact model. Soil Science Society of America Journal 41, 1039-1043.

Hodge, A., Robinson, D., Griffiths, B. S. \& Fitter, A. H. (1999). Nitrogen capture by plants grown in N-rich organic patches of contrasting size and strength. Journal of Experimental Botany 50, 1243-1252.

Huck, M. G., Peterson, C. M., Hoogenboom, G. \& Busch, C. D. (1986). Distribution of dry matter between shoots and roots of irrigated and nonirrigated determinate soybeans. Agronomy Journal 78, 807-813.

JACKSON, L. E. (1995). Root architecture in cultivated and wild lettuce (Lactuca spp.) Plant, Cell and Environment 18 , 885-894.

Johnson, I. R. \& Thornley, J. H. M. (1987). A model of shoot-root partitioning with optimal growth. Annals of Botany 60, 133-142.

KaGE, H. (1992). Zu den ursachen hoher restnitratmengen beim anbau von ackerbohnen. Ph.D. Thesis, University of Gottingen, Germany.

KaGe, H. (1996). Zur relativen Bedeutung des Massenflusses beim Nitrattransport zur Wurzel. Zeitschrift für Pflanzenernährung und Bodenkunde 160, 171-178.

KAGE, H. (1997). Is low rooting density of faba beans a cause of high residual nitrate content of soil at harvest? Plant and Soil 190, 47-60.

KaGe, H. \& Ehlers, W. (1996). Does transport of water to roots limit water uptake of field crops? Zeitschrift für Pflanzenernährung und Bodenkunde 159, 583-590.

KaGe, H. \& STÜtzel, H. (1999a). HUME: an object oriented component library for generic modular modelling of dynamic systems. In Modelling Cropping Systems, ESA conference, Lleida, June 1999 (Eds C. S. M. Donatelli, F. Villabos \& J. M. Villar), pp. 299-300. Lleida, Spain: European Society of Agronomy.

Kage, H. \& Stützel, H. (1999b). A simple empirical model for predicting development and dry matter partitioning in cauliflower (Brassica oleracea L. botrytis). Scientia Horticulturae 80, 19-38.

Kage, H., Kockler, M. \& Stützel, H. (2000). Root growth of cauliflower (Brassica oleracea L. botrytis) under unstressed conditions: measurement and modelling. Plant and Soil 223, 133-147.

Kage, H., Alt, C. \& Stützel, H. (2002). Nitrogen concentration of cauliflower organs as determined by organ size, $\mathrm{N}$ supply and radiation environment. Plant and Soil 246, 201-209.

Kage, H., Alt, C. \& Stützel, H. (2003). Aspects of nitrogen use efficiency of cauliflower. II. Productivity and nitrogen partitioning as influenced by $\mathrm{N}$ supply. Journal of Agricultural Science, Cambridge 141, 17-29.

Kleemola, J., Teittinen, M. \& Karnoven, T. (1996). Modelling crop growth and biomass partitioning to shoots and roots in relation to nitrogen and water availability, using a maximization principle. I. Model description and validation. Plant and Soil 185, 101-111.

KünKele, S. (1996). Einfluß von bodenverdichtungen auf qualität und ertrag von gemüse. Ph.D. Thesis, University of Hannover, Hannover.

Lorenz, H.-P., Schlaghecken, J., Engel, G., Maync, A. \& ZIEGLER, J. (1989). Ordnungsgemäße Stickstoffversorgung im Freilandgemüsebau nach dem kulturbegleitenden NminSollwerte-(KNS) System. Rheinland-Pfalz, Germany: Ministerium für Landwirtschaft, Weinbau und Forsten.

Marquardt, D. W. (1963). An algorithm for least-squares estimation of nonlinear parameters. Journal of the Society for Industrial and Applied Mathematics 11, 431-441.

Monteith, J. L. (1973). Principles of Environmental Physics. London: Edward Arnold.

Navone, R. (1964). Proposed method for nitrate in potable waters. Journal of the American Water Works Association 56, 781-783.

Newman, E. I. (1966). A method of estimating the total root length in a sample. Journal of Applied Ecology 3, 139-145.

Nye, P. H. \& Spiers, J. A. (1964). Simultaneous diffusion and mass flow to plant roots. In 8th International Congress of Soil Science (Bucharest), pp. 535-542.

Peuke, A. D. \& Kaiser, W. M. (1996). Nitrate or ammonium uptake and transport, and rapid regulation of nitrate reduction in higher plants. Progress in Botany 57, 93-113.

Reidenbach, G. \& Horst, W. J. (1997). Nitrate-uptake capacity of different root zones of Zea mays (L.) in vitro and situ. Plant and Soil 196, 295-300.

Robinson, D., Linehan, D. J. \& Gordon, D. C. (1994). Capture of nitrate from soil by wheat in relation to root length, nutrient inflow and availability. New Phytologist 128, 297-305.

ScHENK, M. K. (1998). Nitrogen use in vegetable crops in temperate climates. Horticultural Reviews 22, 185-223.

Strebel, O. \& Duynisveld, W. H. M. (1989). Nitrogen supply to cereals and sugar beet by mass flow and diffusion on a silty loam soil. Zeitschrift für Pflanzenernährung und Bodenkunde 152, 135-141.

Szeicz, G. (1974). Solar radiation for plant growth. Journal of Applied Ecology 11, 617-636.

Thornley, J. H. M. (1972). A balanced quantitative model for root: shoot ratios in vegetative plants. Annals of Botany 36, 431-441.

THORUP-KRISTENSEN, K. (1993). Root growth of nitrogen catch crops and of a succeeding crop of broccoli. Acta Agriculturae Scandinavica, Sect. B, Soil and Plant Science 43, 58-64.

Van Den Boogaard, R. \& Thorup-Kristensen, K. (1997). Effects of nitrogen fertilization on growth and soil 
nitrogen depletion in cauliflower. Acta Agriculturae Scandinavica Section B., Soil and Plant Science 47, $149-155$.

VAn Genuchten, M. T. (1980). A closed-form equation for predicting the hydraulic conductivity of unsaturated soils. Soil Science Society of America Journal 44, 892-898.

Van Genuchten, M. T., LeiJ, F. J. \& Yates, S. R. (1991). The RETC Code for Quantifying the Hydraulic Functions of Unsaturated Soils, Version 1.0. EPA Report 600/2-91/ 065, Riverside, USA: US salinity laboratory.

VAN NoordwiJk, M. \& Wadman, W. (1992). Effects of spatial variability of nitrogen supply on environmentally acceptable nitrogen fertilizer application rates to arable crops. Netherlands Journal of Agricultural Science 40, 51-72.

Wiesler, F. \& Horst, W. J. (1994). Root growth and nitrate utilization of maize cultivars under field conditions. Plant and Soil 163, 267-277.

Wösten, J. H. M. \& Van Genuchten, M. T. (1988). Using texture and other soil properties to predict the unsaturated soil hydraulic functions. Soil Science Society of America Journal 52, 1762-1770.

Wösten, J. H. M., Bannink, M. H. \& Beuving, J. (1986). Waterretentie- en doorlatendheidskarakteristieken van boven- en ondergronden in nederland: de staringreeks ICW-rapport 18 STIBOKA-rapport 1932. 